\title{
Foundation of the Society
}

Enrolling in the EPS :

1. G. Bernardini (Director of the Scuola Normale Superiore, Pisa)

2. L. A. Artsimovich (Academy of Sciences, USSR)

3. L. Cohen (Secretary of The Institute of Physics and the Physical Society, UK)

4. B. P. Gregory (Director-General, CERN)

In the morning of 26 September, the former Steering Committee, other physicists and representatives of $\mathrm{Na}$ tional Societies, gathered in the Council Chamber at CERN. The Constitution of the European Physical Society was on the table before them and they were asked as individuals and as representatives of National Societies whether they wished to join the new Society. Sixty-two individual members and twenty National Societies, Academies and Groups enrolled in the EPS.

\section{Individual Members :}

Former steering committee -

J. B. Adams, Harwell

L. A. Artsimovich, Moscow

G.-J. Béné, Geneva

G. Bernardini, Pisa

H. B. G. Casimir, Eindhoven

L. Cohen, Londón

$H$. Curien, Paris

J. de Boer, Amsterdam

A. de-Shalit, Rehovoth

A. Eklund, Vienna

L. Etienne-Amberg (Mrs), Geneva

$H$. Filthuth, Heidelberg

W. Gentner, Heidelberg

K. Gottstein, Munich

B. P. Gregory, Geneva

$F$. Janouch, Prague

L. Jansen, Geneva
J. M. Jauch, Geneva

P. Jauho, Helsinki

J. Kaczér, Prague

J. R. McĆonnell, Dublin

K. P. Meyer, Bern

F. Netter, Paris

G. Occhialini, Milan

J. M. Otero de Navascues, Madric

F. Perrin, Paris

Ch. Peyrou, Geneva

T. G. Pickavance, Chilton

P. Preiswerk, Geneva

R. Press, London

E. Rudberg, Stockholm

G. H. Stafford, Chilton

G. Szigeti, Budapest

J. Tauc, Prague

P. C. Thonemann, Swanse

I. Ursu, Clu

V. F. Weisskopf, Cambridge, USA

A. Zichichi, Bologna

Delegates and guests -

M. Belmahi, Rabat

A. Berthelot, Paris

G. Boato, Genoa

C. Braams, Jutphaas

J. Brossel, Paris

M. Cini, Bologna

B. Coles, London

W. Dekeyser, Ghent

S. F. Edwards, Mancheste

$J$. Friedel, Paris

M. R. Gavin, London

W. Jentschke, Hamburg

A. Kastler, Paris

M. Kersten, Braunschweig

E. Lüscher, Munich

Z. Plajner, Prague

E. Richter, Frankfurt

K. H. Riewe, Hanau

A. Salam, Trieste

W. Thirring, Geneva

T. di Francia, Bologna

G. Turchanyi, Budapest

Y. Yeivin, Tel Aviv

F. J. Yndurain, Geneva
Societies, Academies and Groups :

Österreichische Physikalische

Gesellscháft

AUSTRIA

(W. Thirring)

Société Belge de Physique

Belgische Natuurkundige Vereniging

BELGIUM

(W. Dekeyser)

Jednota ceskoslovenskych matematik ú a

fyzikú

CZECHOSLOVAKIA

(Z. Plajner)

Suomen Fyysikkoseura

FINLAND

(J. Jauho)

Société Française de Physique

FRANCE

(J. Brossel)

Deutsche Physikalische Gesellschaft e. V. FEDERAL REPUBLIC OF GERMANY

Eötvös Loránd Fizikai Társulat

(M. Kersten)

HUNGARY

(G. Szigeti)

Royal Irish Academy

IRELAND

(J. R. McConnell)

Israel Physical Society

ISRAEL

Società Italiana di Fisica

(Y. Yeivin)

ITALY (G. Toraldo di Francia) Nederlandse Natuurkundige Vereniging

NETHERLANDS

(C. Braams)

Comitetul National de Fizica Romania

RUMANIA

(I. Ursu)

Real Sociedad Española de Fisica y

Quimica

SPAIN (J. M. Otero de Navascues)

Swedish Society of Physicists

SWEDEN

(E. Rudberg)

Schweizerische Physikalische Gesellschaft Société suisse de Physique

SWITZERLAND

(K. P. Meyer)

The Institute of Physics and the Physical Society

UNITED KINGDOM

(M. R. Gavin)

Academy of Sciences of the USSR

USSR (L. A. Artsimovich)

Physical Section of the Yugoslav

Association of Mathematicians, Physicists, and Astronomers

YUGOSLAVIA

(L. Slaus)

European Plasma Physics Group

(P. C. Thonemann)

Groupement AMPERE

(G.-J. Béné)

(Some of the National Societies joined subject to ratification by their own Councils.)
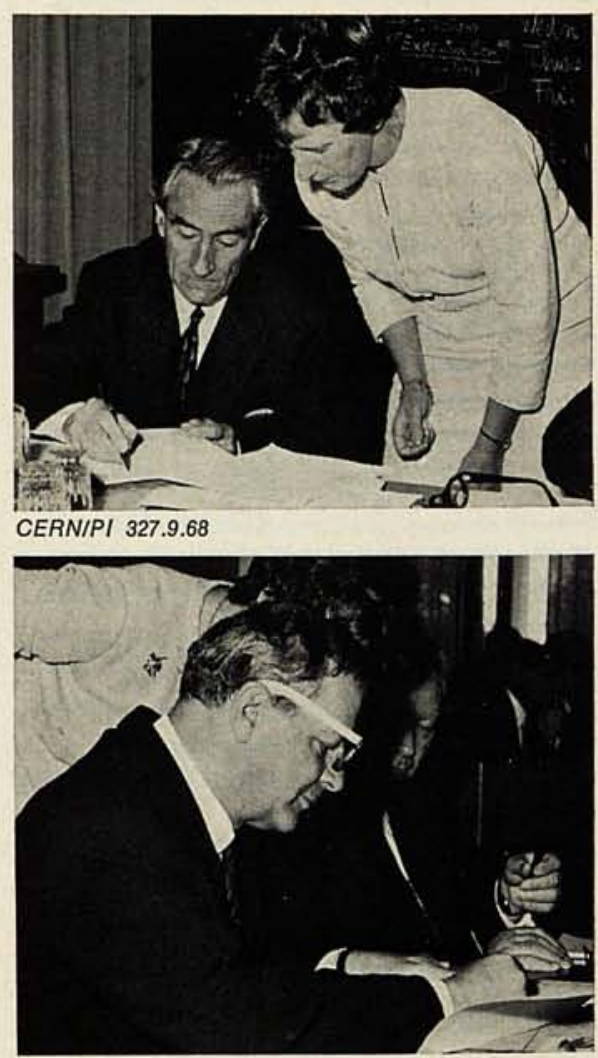

CERNIPI 335.9 .68

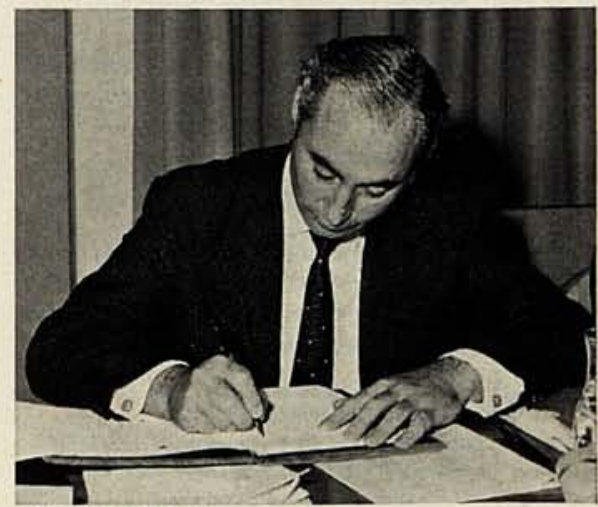

CERNIPI 323.9.68

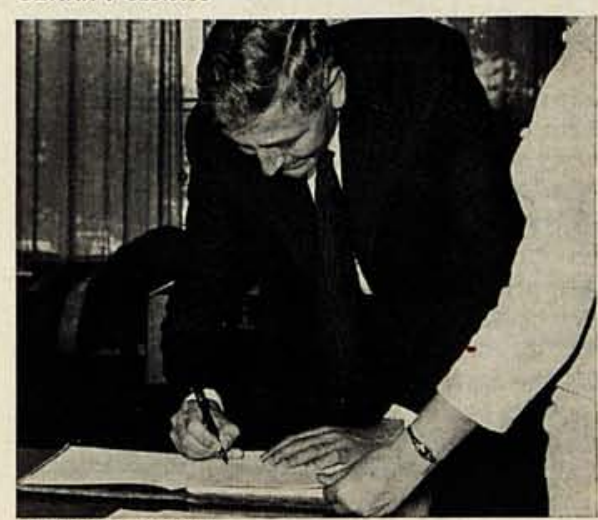

CERNIPI 325.9 .68 


\section{Executive Committee}

The enrolled members of the Society elected the following Executive Committee to guide the affairs of the EPS until the first Council is elected at the Inaugural Conference in Florence. President : Gilberto BERNARDINI Born 20 August 1906 in Florence (Italy).

Studied physics at Pisa, Florence and Berlin. Former President, Italian Physical Society. Present principal position : Rector, Scuola Normale Superiore, Pisa.

Vice-President: Erik Gustaf RUDBERG Born 17 November 1902 in Stockholm (Sweden). Studied physics at Stockholm, Göttingen and London. Chairman, Symbols units nomenclature commission IUPAP. Member, Royal Society of Science and Letters, Sweden. Present principal position : Professor and Secretary, Royal Academy of Science, Stockholm.

\section{Secretary : Laurens JANSEN}

Born 25 March 1923 in Terborg (Netherlands). Studied physics and chemistry at Utrecht and Leyden. Professor, University of Maryland, USA, until 1959. Present principal position : Head, Basic Research, Battelle Institute, Geneva. Vice-Secretary : Frantisek JANOUCH Born 22 September 1931 in Lysa'nad Labem (Czechoslovakia). Studied physics at Leningrad. Habilitation at Charles University Prague. Present principal position : Head, Theoretical Nuclear Physics Department, Nuclear Research Institute, Czechoslovak Academy of Sciences.

Treasurer : Louis COHEN

Born 1925. Studied physics at Manchester and London. Extensive experience in industrial research, covering wide variety of subjects. Present principal position : Secretary (Chief Executive Officer), The Institute of Physics and the Physical Society, London.

Vice-Treasurer: Georges-Jean BENE Born 23 August 1919 in St. Jeoire (France). Studied physics at Paris. Maitre de recherches, CNRS; Secretary-General of Groupement AMPERE. Present principal position : Professor of experimental physics at Universities of Grenoble and Geneva.

Member : Jan de BOER

Born 1911. Studied at Amsterdam. Member, Netherlands Royal Academy of Sciences; Chairman, Foundation for Fundamental Research of Matter of the Netherlands. Present principal position : Professor of theoretical physics, Municipal University of Amsterdam.

Member : Hubert CURIEN

Born 1924. Studied physics at Paris.

Member, Executive Committee, International

Union of Crystallography. Present principal position : Scientific Director, Centre National de la Recherche Scientifique (physical sciences), Paris.

Member: Joseph JAUCH

Born 20 September 1914 in Lucerne (Switzerland). Studied physics at Zürich, Princeton and Minnesota. Professor at University of lowa until 1958. Present principal position : Professor and Director of Theoretical Physics, University of Geneva.

\section{Member : Wolfgang GENTNER}

Born 23 July 1906. Studied physics at Erlangen and Frankfurt. Present principal position: Director, Max-Planck-Institute for Nuclear Physics,

Heidelberg and Professor of Physics, University of Heidelberg.

Member : George SZIGETI

Born 29 January 1905 in Szentes (Hungary). Studied mechanical engineering and technical physics at Budapest. Member of the Presidium of the Hungarian Academy of Sciences until 1964 Present principal position : Director, Research Institute for Technical Physics of the Hungarian Academy of Sciences, Budapest.

\section{The Constitution}

\section{Name - Duration - Seat - Purpose}

Article 1

1. Under the name of European Physical Society (EPS), an association has been organized and incorporated; it is governed by Article 60 and following of the Swiss Civil Code and by the present Constitution.

2. Its duration shall be perpetual.

3. Its seat is in Geneva, Switzerland.

\section{Article 2}

1. The purpose of the Society is and shall be to contribute to and promote the advancement of physics, in Europe and in neighbouring countries, by all suitable means and in particular:

a) by providing a forum for the discussion of subjects of common interest;

b) by providing means whereby action can be taken on those matters which it appears desirable to handle on the international level. 2. In order to fulfil its purpose, the Society shall act either directly or through its members or through specialized divisions created by its members or through corresponding or affiliated societies or groups.

\section{Membership}

Article 3

The membership of the Society shall consist of Ordinary Members, Fellows, Associate Members and Honorary Members.

\section{Article 4}

The following individuals, legal persons or bodies may become Ordinary Members of the Society :

a) individuals who have shown by their contribution to European science, by their professional activity or otherwise, to the Council's satisfaction, that they can further the cause and object of the Society;

b) societies, groups or laboratories organized or existing under the laws of the State of their incorporation or of their seat and which, in the Council's opinion, make a significant contribution to European science;

c) individuals who are members of a society or group which has been accepted as an Ordinary Member of EPS and who fulfil the conditions laid down in the foregoing paragraph provided such individual membership in EPS is not precluded by the Constitution or by-laws of their society or group.

\section{Article 5}

The Society may elect to Fellowship only such individuals as have made a significant contribution to the advancement of physics by independent, original research, or have rendered some other special service to the cause of science.

\section{Article 6}

The Society may also admit Associate Members and Honorary Members who shall have the rights and privileges determined by the by-laws.

\section{Article 7}

The procedure for the election of members is regulated by the by-laws.

\section{Article 8}

Membership of the Society implies strict adherence to the Constitution, to the by-laws and to any lawful decision made or to be made by the organs or officers of the Society.

\section{Article 9}

Members are not personally liable for the debts and liabilities of the Society, which is only liable to the extent of its assets.

\section{Article 10}

Membership is terminated :

a) by withdrawal, if notified at least six months in advance for the end of the year;

b) by death;

c) by expulsion, which can be decided by the Council pursuant to Article 15 and to the by-laws. 